\title{
Studiekompetencedag: Et koncept for udvikling af universitetsstuderendes studievaner
}

Kim J. Herrmann, forskningsmedarbejder, Center for Undervisning og Læring, Aarhus Universitet.

Berit Lassesen, adjunkt, Center for Undervisning og Læring, Aarhus Universitet.

Anna Bager, ph.d.-studerende, Center for Undervisning og Læring, Aarhus Universitet.

Torben K. Jensen, centerleder, Center for Undervisning og Læring, Aarhus Universitet.

\begin{abstract}
Mange universitetsuddannelser udbyder studieteknikkurser eller henviser studerende til private kursusudbydere. Kurserne er velbesøgte, og de studerende er overvejende tilfredse. Den stigende fokus på studieteknik er dog ikke uproblematisk, og derfor er det på tide at diskutere, hoad der kendetegner kvalitet $i$ udvikling af de studerendes studiekompetencer. I denne artikel præsenteres et koncept for en studiekompetencedag som Center for Undervisning og Læring, Aarhus Universitet, har udviklet. De pædagogiske valg bag kurset præsenteres og diskuteres, og erfaringerne evalueres.
\end{abstract}

\section{Baggrund}

Når man starter på en videregående uddannelse, står man over for nye måder at tilegne sig viden på. Man skal overskue store mængder stof, og traditionelt placeres ansvaret for indlæring hos de studerende. Langt det meste læring finder sted - og skal finde sted - når undervisere og studerende ikke er sammen. Herved adskiller universitetet sig fra dét, de fleste studerende har været vant til som elever på ungdomsuddannelserne, hvor en stor del af læringsaktiviteterne foregår i timerne, når elever og lærere er sammen. At være universitetsstuderende stiller derfor store krav til den studerendes evne til at strukturere og organisere egen læring.

Mange studiestartere er ikke bevidste om den ændrede rolle og udvikler uhensigtsmæssige studievaner. Dette ses ofte ved slutningen af første semester, hvor mængden af ulæste tekster tynger. De virkeligt motiverede, nye studerende har ofte store forventninger til deres studium og kaster sig over fagets kerne fra første dag, men selv en meget motiveret studerende risikerer at løbe sur i uddannelsen, hvis ikke der etableres gode studievaner fra start.

Det er dog på ingen måde en let opgave at hjælpe de studerende til at etablere gode studievaner gennem kurser i studieteknik: 
"[at undervise i studieteknik] is inevitably generic provided by study skills specialists, and cannot be equally suitable across a wide range of subject areas. Students will therefore look to departmental staff to provide the more specific advice they need. However, university teachers often find difficulty in providing such advice, so help must then be sought from educational developers who can provide the necessary advice." (Entwistle, 2009, s. 162).

Entwistle beskriver i ovenstående citat den helt centrale udfordring for undervisere i studieteknik, nemlig at 'god' og hensigtsmæssig studiepraksis er forankret i fagets indhold, dets metode, normer og værdier. Kurser i studieteknik må nødvendigvis bevæge sig ud over det generiske og forholde sig til studiepraksis på fagets præmisser.

I denne artikel beskrives konceptet for et kursus i studieteknik, som siden 2010 har været tilbudt fagene på School of Business and Social Sciences, Aarhus Universitet. Først beskrives den forskning, som de seneste fyrre år har undersøgt sammenhængen mellem studiestrategier og studerendes oplevelser af læringsmiljøet. Ydermere inddrages teorier om disciplinære forskelle og deres betydning for studiekompetencer. Dette følges af en redegørelse for de bærende pædagogiske principper for dagen, hvorefter konceptet for studiekompetencedagen beskrives i detaljer. Der redegøres kort for praktiske erfaringer med konceptet, og i artiklens sidste del diskuteres, hvorvidt konceptet og dets bærende principper kan overføres til andre fagområder.

\section{Studievaner og perception af læringsmiljøet}

Studerende på videregående uddannelser skal kunne forstå, anvende og forholde sig kritisk til fagenes teori, empiri og metode og dette på et niveau, som er accepteret inden for den videnskabelige genre. Dette involverer i mange tilfælde brugen af komplekse kognitive processer, og gennem flere årtier er der blevet forsket i de universitetsstuderendes læreprocesser og motivation. Ud af denne forskning er vokset begrebet 'læringsstrategi', der beskriver et kvalitativt aspekt ved læring og handler om, hvordan den studerende oplever og organiserer sit læringsarbejde. De to kontrasterende typer af strategier er blevet kendt som henholdsvis overfladestrategi, hvor den studerende tilegner sig (ofte) store mængder af informationer uden at forstå betydningen af disse (Ramsden, 1992) og dybdestrategi, hvor den studerende er motiveret af en ægte præference for, og evne til, at fordybe sig i emnet og forstå den underliggende struktur i undervisningsmaterialet (Biggs, 2012).

Læringsstrategier og studievaner er reaktioner på det undervisningsmiljø, de studerende lærer i. Dette ligger i begrebets relationelle natur (Ramsden, 1992). De studerendes læreprocesser og valg af læringsstrategier hænger i høj grad sammen med de studerendes tidligere erfaringer ( $f x$ fra gymnasiet), deres opfattelse af de nuværende 
situationelle faktorer (underviserens engagement, undervisningsformatet og indholdet af dette) og deres oplevelse af de institutionelle faktorer så som eksamensformer og bedømmelseskriterier.

\section{Constructive alignment}

Disse forskningsresultater viser, at studerende ikke er prædestinerede til bestemte studievaner eller studiestrategier, men at universitetet og i særdeleshed underviserne har et vist spillerum i forhold til at påvirke de studerendes studievaner. Ikke ved at ændre de studerende, men ved at ændre den læringssituation, som de studerende oplever (Prosser \& Trigwell, 1999).

Biggs (2012) har fremsat den påstand, at et effektivt læringsmiljø kræver overensstemmelse (constructive alignment) mellem læringsmål, undervisningsaktiviteter og bedømmelseskriterier. Hvis læringsmålet for eksempel er, at de studerende efter endt undervisningsforløb skal kunne relatere begreber og anvende deres viden på cases, vil det ikke være kohærent med en eksamensform, hvor de studerende udelukkende skal svare på korte redegørende spørgsmål. I dette tilfælde ville eksamensformen modarbejde læringsmålene. Nyere forskning tyder på, at oplevelse af alignment i undervisningen hænger positivt sammen med dybdelæring og negativt sammen med overfladelæring (Entwistle, 2009; Parpala et al., 2013).

\section{Fagenes indre logik}

Vi skal imidlertid også være opmærksomme på, at gode studievaner og hensigtsmæssige læringsstrategier kommer forskelligt til udtryk alt efter fagenes indhold. Derfor har forskere i de forløbne år i stigende grad undersøgt betydningen af fagdisciplinernes særlige praksisser (ways of thinking and practicing). Det er væsentligt set $\mathrm{i}$ relation til studiekompetencer, fordi:

"Disciplines provide particular lenses or frameworks through which to explore, understand and act upon the world. They can be conceived as 'tools of learning'[...], each characterized by certain ways of thinking, procedures and practices that are characteristic of its community." (Kreber, 2009, s. 16).

Et eksempel på forskelle indlejret i fagenes kerne er, at et identificeret mål for historiestuderende er at lære at forstå, hvordan historien konstrueres gennem historieskrivningen, og hvorfor det er særlig vigtigt at distancere sig fra egne fordomme, når man fortolker historisk materiale, mens det i biologi er et mål at lære, at metoden til at afdække videnskabelig evidens er væsentligere end selve indholdet, da indholdet hele tiden forældes af nye forskningsresultater (Entwistle, 2009). Sådanne indre logikker findes i alle fag og er ofte uudtalte, hvilket kan gøre det svært for de studerende at blive fortrolige med faget. I dette lys handler studiekompetencer ikke så meget om at lære en bestemt teknik men snarere om at blive udlært i fagets praksis, herunder i arbejdet mellem timerne. 


\section{Dagens bærende principper}

Den efterhånden omfattende forskningslitteratur om studiestrategier, perception, alignment og fagenes indre logikker må nødvendigvis få konsekvenser for organiseringen af et kursus om studiekompetencer. Derfor bygger studiekompetencedagen på en række bærende principper.

For det første, at et oplæg om studieteknik fra udefrakommende eksperter ikke bør stå alene. Nogle temaer så som planlægning af hverdagen, organisering af læsegrupper mv. går igen på alle fag, men hvad, der konstituerer god studiepraksis, er lige så afhængigt af faget og fagets metoder. Et kursus i studiekompetencer bliver nødvendigvis nødt til at forholde sig til faget i så vidt et omfang, som det er muligt.

Af dette følger for det andet, at et kursus i studieteknik ikke alene bør adressere de studerende men også underviserne. Underviserne er repræsentanter for faget, lige som det er underviserne, der fastsætter læringsmål, organiserer læringsaktiviteter, og bedømmer eksamener. Mange velmente råd om studieteknik og dybdelæring vil være forgæves, hvis eksamen belønner overfladelæring, hvis der ikke er overensstemmelse mellem mål og aktiviteter, eller hvis intentionen bag de didaktiske valg ikke er klart kommunikeret.

For det tredje bør studiekompetencedagen i sig selv være et eksempel på god universitetspædagogisk praksis, dvs. et eksempel på, hvordan man, selv på uddannelser med store årgange, kan motivere de studerende til at arbejde aktivt med det faglige stof før, under og efter undervisningen. Ligeledes bør dagen også demonstrere, hvordan denne aktivering med stor fordel kan understøttes ved brug af e-læring. Implementering af disse tiltag er beskrevet nedenfor.

\section{School of Business and Social Sciences, Aarhus Universitet}

Aarhus School of Business and Social Sciences har cirka 14.000 studerende fordelt på syv institutter. Fakultetet udbyder en række uddannelser, der - på trods af en samfundsfaglig fællesnævner - har et meget forskelligt fagligt indhold. Hvert år optages flere tusinde nye studerende på uddannelser så som Økonomi, Psykologi, Statskundskab, Jura, Erhvervskommunikation mv. Ud over de disciplinære forskelle er studenterpopulationen - bl.a. som resultat af forskelle i kvalifikationskrav - meget forskellig fra fag til fag.

Studiemiljøundersøgelserne fra 2007 og igen 2011 dokumenterede en række udfordringer i studiemiljøet på fakultetet set fra et universitetspædagogisk perspektiv. Mange studerende var i tvivl om, hvad læringsmålene var, og mange fandt det uklart, hvad bedømmelseskriterierne var til eksamen. Yderligere dokumenterede undersøgelsen, at flertallet af studerende fandt det meget svært at få feedback på 
studiearbejdet (Aarhus Universitet, 2011). Det var på foranledning af disse tal, at studiekompetencedagen blev efterspurgt, og i dag afholdes der hvert år ni studiekompetencedage.

\section{Beskrivelse af studiekompetencedag}

Målet for dagen er 1) at synliggøre de udfordringer, man står overfor som studerende og give viden om, hvad der belønnes på universitetet; 2) at udbrede kendskab til og opbygning af hensigtsmæssige studievaner; 3) at fremme konstruktivt samarbejde de studerende imellem; 4) at synliggøre de didaktiske valg bag tilrettelæggelsen af undervisningen.

En væsentlig pædagogisk pointe med den faglige dag er, at de studerende skal arbejde aktivt og formaliseret i mindre grupper med det sigte at opnå gensidig feedback, fælles forståelse af faglighed og forventninger til fremtidige aktiviteter. Dagens program veksler mellem fælles aktiviteter i form af korte forelæsninger og oplæg samt arbejde i mindre grupper. Dagen indledes med en introduktion om de generelle udfordringer og forventninger, som de studerende kommer til at møde i et akademisk uddannelsesforløb. I løbet af dagen får deltagerne endvidere mulighed for at mødes med et panel af erfarne medstuderende for at diskutere studievaner, ligesom de får mulighed for at møde undervisere fra første semester og høre disse fremlægge deres faglige og pædagogiske valg med efterfølgende mulighed for at stille spørgsmål til disse.

\section{Materialer}

Som materiale til brug for forberedelse af dagen henvises til passager fra Studiehåndbogen (Jørgensen et al., 2011). Passagerne adresserer fire temaer: Læsning, notatteknik, læsegruppearbejde og gode studievaner. I teksten forklares og beskrives temaerne indgående, ligesom der gives konkrete eksempler på, hvordan man kan gribe opgaven med fx notatteknik eller strukturering af læsning an i praksis. Det skriftlige materiale har et omfang på cirka 40 sider, som de studerende bliver bedt om at forberede dele af inden dagen.

\section{Forberedelse}

De studerendes forberedelse til studiekompetencedagen er beskrevet i en læringssti, som lægges på universitetets e-læringsplatform. De studerende bliver inddelt i grupper bestående af fire personer og på forhånd bedt om at forberede et af de fire ovenstående temaer. Udover at brugen af e-læring sikrer, at hver enkelt studerende på forhånd er oplyst om, hvilket tema de skal arbejde med på dagen, giver dette desuden deltagerne mulighed for at arbejde på egne præmisser i forhold til muligheder og behov. De studerende skal endvidere bruge læringsstien til at publicere deres egne og læsegruppens overvejelser om fremtidig praksis og det faglige udbytte af dagen. 


\section{Program}

Dagen begynder med en forelæsning, som forestås af en af CUL's forskere. Temaet for denne forelæsning er mere overordnet, hvad der anses for at være god studiepraksis på universitet, men tager også som regel udgangspunkt i universitetets studiemiljøundersøgelse og resultaterne for den specifikke uddannelse.

Herefter fortsætter dagens program ude på holdene, hvor én af holdenes studenterundervisere styrer afviklingen af de næste programpunkter. Først sættes de studerende til at diskutere den litteratur og de videoer, som de har beskæftiget sig med som forberedelse til dagen. Efter en opsamling af de vigtigste punkter arbejder de studerende med, hvordan de kan anvende denne viden i deres egen studiepraksis. Hver læsegruppe får til opgave at skrive et kort dokument og uploade det til elæringsplatformen. Dokumentet skal indeholde tre konkrete punkter, hvor læsegruppen har tænkt sig at ændre studiepraksis.

Tabel 1. Program for studiekompetencedag

\begin{tabular}{|c|c|c|}
\hline Tid & Aktivitet & Sted \\
\hline 9.00 & Studielederen byder velkommen & \multirow[t]{2}{*}{ Aulaen } \\
\hline 9.15 & $\begin{array}{l}\text { Forelæsning: Hvad ved vi om læring, et godt læ- } \\
\text { ringsmiljø og organisering af undervisning? }\end{array}$ & \\
\hline 10.00 & $\begin{array}{l}\text { Pause - holdene går til mindre lokaler med stu- } \\
\text { denterunderviser }\end{array}$ & \multirow[t]{5}{*}{ Mindre lokaler } \\
\hline 10.15 & $\begin{array}{l}\text { Gruppearbejde om god studieteknik } \\
\text { 1. Runde: Personer, der hjemmefra har sat sig særlig } \\
\text { grundigt ind i samme tema, sætter sig sammen, } \\
\text { drøfter pointerne og producerer et ark med ho- } \\
\text { vedpunkter. } \\
\text { 2. Runde, omgruppering til faste læsegrupper: Hver } \\
\text { studerende præsenterer pointerne fra 1. runde for } \\
\text { sin læsegruppe. } \\
\text { 3. Opsamling. Hver læsegruppe producerer en } \\
\text { sammenfattende tekst som uploades til AULA }\end{array}$ & \\
\hline 11.30 & Frokost & \\
\hline 12.15 & $\begin{array}{l}\text { Besøg af panel af ældre studerende: Hvad gør I, } \\
\text { hvad fungerer for jer? }\end{array}$ & \\
\hline 13.00 & $\begin{array}{l}\text { Kort plenumdiskussion: Hvilke spørgsmål kun- } \\
\text { ne I tænke jer at stille underviserne om den må- } \\
\text { de, undervisningen tilrettelægges og udføres på? }\end{array}$ & \\
\hline 13.15 & Pause - vi går over i Aulaen & \multirow[t]{2}{*}{ Aulaen } \\
\hline 13.30 & $\begin{array}{l}\text { Hvorfor gør vi, som vi gør? Underviserne be- } \\
\text { grunder de valg, der ligger bag organiseringen af } \\
\text { undervisningen. }\end{array}$ & \\
\hline 13.45 & $\begin{array}{l}\text { Lærerne i krydsild: Hvorfor skal vi ...? } \\
\text { Studerende stiller spørgsmål til undervi- } \\
\text { serne om de pædagogiske valg. }\end{array}$ & \\
\hline 14.30 & Afslutning & \\
\hline
\end{tabular}


Efter en frokost mødes holdet igen til en paneldiskussion, hvor ældre medstuderende fortæller om deres erfaringer og studiepraksis, og hvor de førsteårsstuderende kan stille spørgsmål. Studiekompetencedagen afsluttes med en fælles session, hvor de studerende møder underviserne for fagene på første semester. Hver underviser har 5 minutter til at fremlægge et eller flere centrale pædagogiske valg i undervisningsforløbet. Herefter kan de studerende stille underviserne spørgsmål.

\section{Praktiske erfaringer og evaluering af dagen}

Studiekompetencedagen blev først udviklet og udbudt i 2010 og har undergået forandringer i takt med de erfaringer, som er gjort gennem de forløbne tre år. Mange introduktioner til studieteknik for nye studerende lægges i begyndelsen af semesteret. Studiekompetencedagen er derimod placeret i november måned, hvilket er tre måneder henne i studieforløbet. At lægge dagen senere på semesteret har to fordele: For det første undgås det, at dagen drukner i alle de nye indtryk, som de studerende i forvejen skal forholde sig til ved studiestart. For det andet sikres det, at de studerende har erfaringer, som de kan relatere materialet til, samt at de studerende på dette tidspunkt vil have etableret en praksis, som de kan forholde sig kritisk og konkret til. Dagen er dog lagt så tilpas tidligt, at den ikke falder sammen med eksamensperioden.

Selve kurset er 'billigt' forstået på den måde, at der gøres brug af studiernes egne ressourcer, og at den eneste større udgift er løn til studenterundervisere. Men hvad angår organiseringen af kurset - særligt i etableringsfasen - er der brug for god tid. Der skal holdes møder med underviserne, studenterunderviserne skal orienteres om deres rolle på dagen, der skal etableres læringsstier, de studerende skal orienteres grundigt mv.

Dagen har affødt en del empiriske data i form af en evalueringsrapport (byggende på feedback fra 23 studiegrupper), de studerendes uploadede planer for fremtidig studiepraksis samt udtalelser fra studieledere (Cultivate, 2013). Disse kilder giver et billede af de studerendes oplevelse og udbytte af dagen.

De studerende er overvejende tilfredse med dagen. Temaerne (notatteknik, læsning, planlægning og samarbejde) opleves relevante, og man kan ved at læse de planer, som de studerende uploader til e-læringsplatformen, se, at de studerende især er optaget af planlægningen af hverdagen og samarbejdet med læsegruppen. Dette drejer sig fx om at etablere faste rutiner, lave ugeplaner, og finde læsepladser, hvor de studerende har ro til at arbejde og ikke distraheres. For nogle studerende handler planerne også om at højne selvdisciplinen, adskille 'arbejde' og fritid og at kunne holde fri med god samvittighed. Typiske planer for læsegruppearbejdet er eksplicitering og forventningsafstemning i forhold til ambitionsniveau, mødekultur, fælles og individuelt ansvar og konstruktiv feedback. 
De studerende er meget glade for at møde panelet af ældre studerende, lige som den afsluttende debat med de undervisningsansvarlige bliver værdsat. Studielederne fortæller, at den afsluttende debat gav underviserne indblik i de studerendes oplevelser af undervisningen, lige som den gav underviserne en lejlighed til at signalere interesse for de studerende og åbenhed omkring de pædagogiske valg og overvejelser.

\section{Diskussion og anbefalinger}

I takt med at en større og mere heterogen gruppe af studerende optages på landets universiteter, bliver behovet for udvikling af de studerende studiekompetencer stadigt mere påtrængende. I denne artikel har vi beskrevet en studiekompetencedag, sådan som den foregår på uddannelser under School of Business and Social Sciences, Aarhus Universitet. Vi har selv lånt ideer og materialer andre steder fra, og på samme måde vil vi invitere til, at man efterligner eller lader sig inspirere af vores koncept.

Et sådant kursus vil selvfølgelig skulle modificeres alt efter, hvor det implementeres. Vi har udviklet kurset inden for rammerne af et samfundsvidenskabeligt fakultet, og pædagogiske erfaringer og valg rejser ikke uhindret over faggrænserne. Alligevel vurderer vi, at rammen for studiekompetencedagen og de bærende pædagogiske ideer kan anvendes bredt, netop fordi konceptet integrerer generel studieteknik med fagets egne præmisser.

Rammen for studiekompetencedagen hviler på forudsætninger, som vi mener, bør gælde generelt for kurser i studieteknik. For det første, at studieteknikkurser bør forholde sig til og integrere fagets egne måder at tænke og praktisere på for at hjælpe studerende med at afkode fagets indre logikker. Vi har set eksempler på privat udbudte kurser i studieteknik, som lægger så meget vægt på memoteknik og hurtiglæsning, at studerende kunne få det indtryk, at en universitetsuddannelse (kun) går ud på at lære en masse stof udenad. Undervisning i studieteknik, som er afkoblet fra faget risikerer at overse selve 'kernen' i faget, hvilket vil sige de praksisser og måder at tænke på, som er karakteristiske for netop dette fag. I værste fald kan de velmente råd stå i direkte modsætning til fagets mål.

Den anden bærende ide er, at kurser i studieteknik bør rette sig mod studerende såvel som undervisere. Som forskere og undervisningsudviklere har vi kun begrænset indsigt i selve fagets indhold. Underviserne er derimod bærere af fagets praksis og fagets værdier. Det er underviserne, der med formuleringen af læringsmål, valg af undervisningsaktiviteter og bedømmelse af eksamener rammesætter de studerendes læring og dermed også har den mest direkte indflydelse på den studiepraksis og de læringsstrategier, som de studerende i sidste ende vælger. Det er dermed også underviserne, der har den største gennemslagskraft og legitimitet over for de studerende. 
Det er vores erfaring, at der er brug for en meget klar forventningsafstemning, hvad angår fordeling af roller og ansvar. Ofte bliver vi nødt til at forklare, hvorfor det er nødvendigt at også underviserne møder op til en dag om de studerendes studievaner. Studieteknik opfattes af nogle undervisere som generisk - det vil sige som noget, der ikke har med selve faget at gøre - og blandt nogle undervisere trives åbenbart den uheldige forestilling, at studievaner er noget, de studerende slet og ret har. Forskningen viser imidlertid, at studiestrategier ikke er uforanderlige, og at studiestrategier blandt andet påvirkes af de studerendes oplevelser af læringsmiljøet. Det er vigtigt at forstå, at uhensigtsmæssige studievaner ikke nødvendigvis er udtryk for dovenskab, irrationalitet eller manglende motivation (selv om det nogle gange er tilfældet). Studerende handler meningsfuldt i overensstemmelse med undervisningsmiljøet, som de oplever det - for eksempel hvad de studerende tror, der forventes af dem. Studiekompetencedagen er med til at synliggøre den mulige diskrepans mellem undervisernes intention med læringsmiljøet og de studerende faktiske oplevelser af læringsmiljøet, og i de tilfælde, hvor diskrepansen afdækkes, gives både undervisere og studerende grundlag for at ændre praksis.

At inddrage underviserne har også en anden fordel: Nemlig at dagen - ud over at handle om hensigtsmæssig studiepraksis - i lige så høj grad kommer til at handle om hensigtsmæssig undervisning. Det falder nogle undervisere svært at redegøre for de didaktiske valg, og dagen er en oplagt mulighed for at diskutere - og i nogle tilfælde også hjælpe underviserne til at se - begrundelserne for den måde, faget er organiseret på. I de tilfælde, hvor begrundelserne er manglende eller uhensigtsmæssige, giver det mulighed for at diskutere, om undervisningen kan indrettes på en bedre måde. På et mere overordnet plan er studiekompetencedagen således en god lejlighed til at diskutere universitetspædagogik med underviserne ude på fagene.

Vi betragter først og fremmest dagen som en målrettet og struktureret samtale studerende imellem og mellem studerende og undervisere. Den universitetspædagogiske enheds opgave er at iscenesætte denne samtale, så den bliver konkret og konstruktiv.

Kim Jesper Herrmann er cand.scient.pol. med en ph.d.-grad i Social Sciences and Business fra Aarhus Universitet med særligt fokus på samfundsfagenes didaktik. Han har siden 2007 været tilknyttet Center for Undervisning og Læring, Aarhus Universitet. Hans primære forskningsinteresser er studerendes lxringsstrategier, studentercentreret undervisning og samspillet mellem undervisere og studerende.

Berit Lassesen er adjunkt, ph.d. på Center for Undervisning og Læring og forsker primært $i$ forhold, der vedrører studerende på de videregående uddannelser - herunder motivationsfaktorer og forhold $i$ øvrigt, der har betydning for de studerendes etablering af læringsstrategier. 
relation til deres fag. Anna Bager har tillige arbejdet med Aarhus Universitets studiemiljøundersøgelser $i$ både 2007 og 2011.

Torben Kristian Jensen er centerleder for Center for Undervisning og Læring. Udover ledelses- og udviklingsopgaver underviser han ph.d.-vejledere på Business and Social Sciences samt adjunkter fra hele Aarhus Universitet.

\section{Litteratur}

Aarhus Universitet (2011). Studiemiljø2011: Rapporterne 1-7, Aarhus Universitet. Tilgængelig: http://www.au.dk/studiemiljo2011 (tilgået 26.08.13).

Cultivate (2013). Faglige dage om studieteknik giver nye studerende gode vaner, 3. udgave, Center for Undervisning og Læring, Aarhus Universitet. Tilgængelig: http://cultivate.au.dk/issue03/ (tilgået 26.08.13).

Biggs, J. (2012). What the student does: Teaching for enhanced learning, Higher Education Research \& Development, 31(1), 39-55.

Entwistle, N. (2009). Teaching for Understanding at University: Deep Approaches and Distinctive Ways of Thinking, Basingstoke: Palgrave-Macmillan.

Jørgensen, P., Rienecker, L. \& Pipa, T. (2011). Studiehåndbogen: for studiestartere på videregående uddannelser, 2. udg., Frederiksberg: Samfundslitteratur.

Kreber, C. (2009). The University and its Disciplines, London: Routledge.

Parpala, A., Lindblom-Ylänne, S., Komulainen, E. \& Entwistle, N. (2013). Assessing students' experiences of teaching-learning environment and approaches to learning: Validation of a questionnaire in different countries and varying context, Learning Environment Research, 16(2), 201-215.

Prosser, M. \& Trigwell, K. (1999). Understanding Learning and Teaching: The Experience in Higher Education, Buckingham: SRHE and Open University Press.

Ramsden, P. (1992). Learning to Teach in Higher Education. London: Routledge. 